See Article page 1664 .

\section{Commentary: Three-dimensional printing: More than a roadmap}

\author{
Alexander J. Sbrocchi, MD, and Barry C. Gibney, DO
}

Three-dimensional (3D) printing technology has been used in the generation of product prototypes for decades. ${ }^{1}$ The technology has spread into the surgical realm and has been used in a broad range of applications, namely preoperative planning, intraoperative modeling, education/training, patient counseling, and even implantable materials. Easily the most used application has been in preoperative planning, where 3D printed models have aided in the translation of detailed 2-dimensional images from cross-sectional imaging into tactile models for the clinician to examine. ${ }^{2}$

In this issue of the Journal, Huang and colleagues ${ }^{3}$ present their experience using custom Y-stents for the treatment of airway-gastric fistulas following esophagectomy in 6 patients. The fistulas were identified early after surgery, an average of 10 days, and ranged in size from 5 to $20 \mathrm{~mm}$, with a location either in the trachea, carina, or right main bronchus. Their group used 3D-printed molds of the airway to create implantable covered stents customized for the carina angle and take off of the right upper lobe bronchus. The authors report a $100 \%$ fistula closure rate, with a 41-day median length of stay following stent placement, minimal stent-related complications, and durable closure with follow-up of 2 years. Although rare, postesophagectomy airway-gastric fistula represents a potentially devastating complication, with mortality rates approaching $30 \%$, and the potential for long-term issues with oral alimentation. ${ }^{4}$ Traditional teaching dictates operative repair with interposition of well vascularized tissue, such as muscle or omentum. $^{5}$

These results ultimately represent feasibility of a novel treatment and will need to be replicated in a larger series
Check for updates

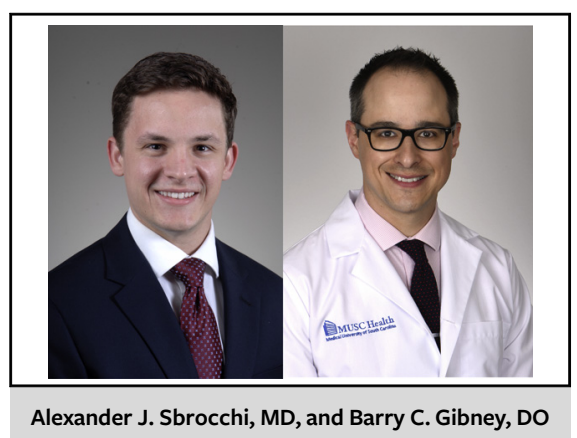

CENTRAL MESSAGE

3D printing has applications

beyond modeling and surgical

planning.

to determine true safety and efficacy. Despite this limitation, Huang and colleagues' use of 3D printing is an excellent display of innovation that may fundamentally change treatment options for this challenging complication. As surgeons, we should embrace technological advancements and be unafraid to challenge surgical dogma. One can hope this represents a kick-start to the expanded use of 3D printing technology.

\section{References}

1. Ventola CL. Medical applications for 3D printing: current and projected uses. $P T$. 2014;39:704-11.

2. Malik HH, Darwood AR, Shaunak S, Kulatilake P, El-Hilly AA, Mulki O, et al. Three-dimensional printing in surgery: a review of current surgical applications. J Surg Res. 2015;199:512-22.

3. Huang W, Shan Q, Wu Z, Li H, Zhou M, Ding X, et al. Retrievable covered metallic segmented Yairway stent for gastrorespiratory fistula of carina or main bronchi. J Thorac Cardiovasc Surg. 2021;161:1664-71.e2.

4. Balakrishnan A, Tapias L, Wright CD, Lanuti MX, Gaissert HA, Mathisen DJ, et al. Surgical management of post-esophagectomy tracheo-bronchial-esophageal fistula. Ann Thorac Surg. 2018;106:1640-6.

5. Reed MF, Mathisen DJ. Tracheoesophageal fistula. Chest Surg Clin North Am. 2003;13:271-89.

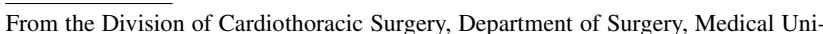
versity of South Carolina, Charleston, SC.

Disclosures: Authors have nothing to disclose with regard to commercial support.

Received for publication March 24, 2020; revisions received March 24, 2020; accepted for publication March 25, 2020; available ahead of print April 8, 2020.

Address for reprints: Barry C. Gibney, DO, 30 Courtenay Dr, Suite BM 203, MSC 295, Charleston, SC 29425 (E-mail: gibney@musc.edu).

J Thorac Cardiovasc Surg 2021;161:1672

$0022-5223 / \$ 36.00$

Copyright (c) 2020 by The American Association for Thoracic Surgery

https://doi.org/10.1016/j.jtcvs.2020.03.064 